\title{
講演 8
}

\section{放射線・治療 板澤明子}

\section{はじめに}

臓器・機能を温存したまま癌治療のできる放射線治療 は, 根治治療から緩和治療まで幅広い適応がある。また, 近年は放射線治療装置や技術の高度化が進んでいる。本 稿では放射線治療における基礎事項と, 肺癌領域におけ る放射線治療の適応について解説する.

\section{1. 放射線治療総論}

\section{1 放射線の種類}

放射線とは, 電離作用を持つエネルギーの高い電磁波 と粒子の総称である。臨床上最も一般的な放射線は $\mathrm{X}$ 線であり, 直線加速器 (リニアック：Linear accelerator) を用いて発生させる。粒子線治療では陽子線や重粒子線 (炭素線)が用いられ, サイクロトロンやシンクロトロン という大型加速器で発生させる.

放射線療法で用いる単位：Gy（グレイ）とは，単位質 量（1 kg）あたりに物質が吸収するエネルギー量（J/kg） である(吸収線量)。一方, 各組織や臓器の被ばく線量を 表す単位である Sv（シーベルト）とは, 吸収線量（Gy） に放射線の種類による影響の強さを加味した係数を乗じ たものである．X 線の場合は $1 \mathrm{~Gy} \fallingdotseq 1 \mathrm{~Sv}$ である.

\section{2 放射線の生物効果}

正常蔵器に生じる影響を有害事象といい, 治療期間中 から直後に生じる早期有害事象と, 放射線治療後数か 月～数年後で発症する晚期有害事象がある．前者は一定 量の放射線量が投与されれば必発であるが一時的であ り，多くは自然軽快する。一方，後者は頻度が低いもの の, 不可逆的で治癒困難である. また, 一回線量の影響 を受けやすいのも後者である.

放射線は総線量を数回に分けて治療する分割照射が一 般的であり，以下の種類がある.
(1)通常分割照射

一日 1 回, $1.8 \sim 2.0 \mathrm{~Gy} /$ 回を週 5 回照射する最も一般的 な照射法.

(2)加速過分割照射 (accelerated hyperfractionation : AHF)

治療期間を短縮することにより，治療期間中の再増殖 の影響を少なくする目的で行われる。限局型小細胞肺癌 （LD-SCLC）では標準的に行われている。

(3)過分割照射 (hyperfractionation : HF)

晚期有害事象のリスク低減を目的に一回線量を小さく する。一日 2 回, 1〜 $1.2 \mathrm{~Gy} /$ 回程度であることが多い.

(4)小分割 (寡分割) 照射（hypofractionation）

一回 3〜 4 Gy 以上を用い短期間で治療を行う方法. 後 述する定位放射線治療のほか, 緩和的治療の際には一般 的である。

\section{3 治療計画}

放射線治療を行うためには，寝台がフラットな CTに て治療時の体位で撮影した CT 画像を用いて治療計画を 行う.この際, 治療計画装置と呼ばれるワークステーショ ンを用い,この計画用 CT 上に以下の標的体積 (図 1) を 決定したうえで，照射方向・門数・線量などが決定され る。

- 肉眼的腫瘍体積 (GTV : gross tumor volume) 画像等で確認できる腫瘍組織.

-臨床標的体積 (CTV : clinical target volume) がん細胞が存在する可能性のある体積. GTV 周辺の微 視的浸潤, 所属リンパ節領域など.

- 内的標的体積 (ITV : internal target volume) CTVに体内藏器の動きによる影響を含めた体積.

・計画標的体積 (PTV : planning target volume) ITVに毎回の照射における設定誤差を加えた体積. こ のPTVに対し処方線量を決定する. 


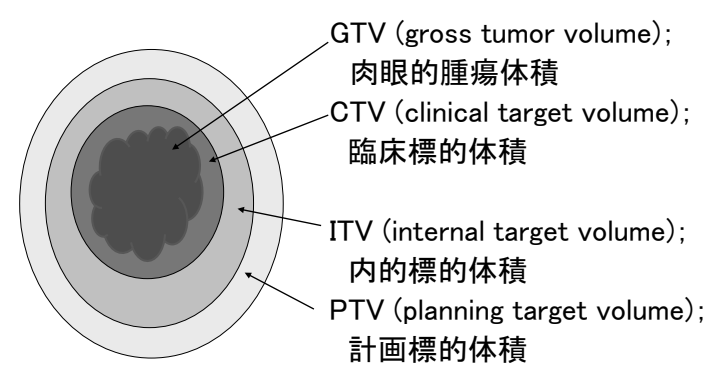

図 1.

\section{·危険臟器 (OAR : organ at risk)}

脊髄, 消化管など小さな範囲でも重大な障害が発生す る直列臟器と, 肺, 肝臓, 腎臓など少ない線量でも広範 囲に照射されると障害が発生する並列臟器がある.

\section{4 放射線治療の実際と高精度放射線治療}

肺癌領域では,リニアックを用いた X 線による三次元 原体照射 (three-dimensional conformal radiation therapy；3DCRT）が一般的に用いられている。リニアック の照射口にある多分割絞り (multileaf collimator；MLC) を用いて，ビーム毎にターゲット形状に合わせた照射野 を形成して行う照射法である.

定位放射線治療とは, 高い精度で(脳で $1 \mathrm{~mm}$ 以内, 体 幹部で $5 \mathrm{~mm}$ 以内）多方向からターゲットに対して集中 的に放射線を照射する技術である，一回で治療する場合 を定位手術的照射 (stereotactic radiosurgery；SRS), 数 回に分割して照射する場合を定位放射線治療 (stereotactic radiotherapy；SRT）という. 主に少数脳転移の際に 適応となる，体幹部に対する SRT は体幹部定位放射線 治療（stereotactic body radiotherapy；SBRT）といい, 胸部領域では原発性肺癌では直径が $5 \mathrm{~cm}$ 以内でかつ転 移のないもの, 転移性肺癌では直径が $5 \mathrm{~cm}$ 以内でかつ 3 個以内でかっ他病巣のないものが保険適応となってい る.

強度変調放射線治療（intensity modulated radiation therapy：IMRT) とは, 3DCRT の進化形であり, 不均一 な放射線強度を持つ照射ビームを多方向から照射するこ とにより, 病巣部に最適な線量分布を得る放射線治療法 である.ターゲットの形状が複雑な場合や OAR が隣接 する場合でも OARへの線量を抑えつつターゲットへの 線量を確保することが可能となる，肺癌領域では，並列 臓器である肺への広範囲な低線量被ばくが生じやすいた め, 適応については慎重を要する.

粒子線治療では, 実臨床では陽子線ないし重粒子線(炭 素線）が用いられる。体の一定の梁さで集中的にエネル ギー吸収（ブラッグピーク）が起きるため（図 2), 正常 組織の放射線量を減らし腫瘍に放射線を集中しやすい. 肺癌領域に扔いては, 粒子線特有の線量集中性を生かし

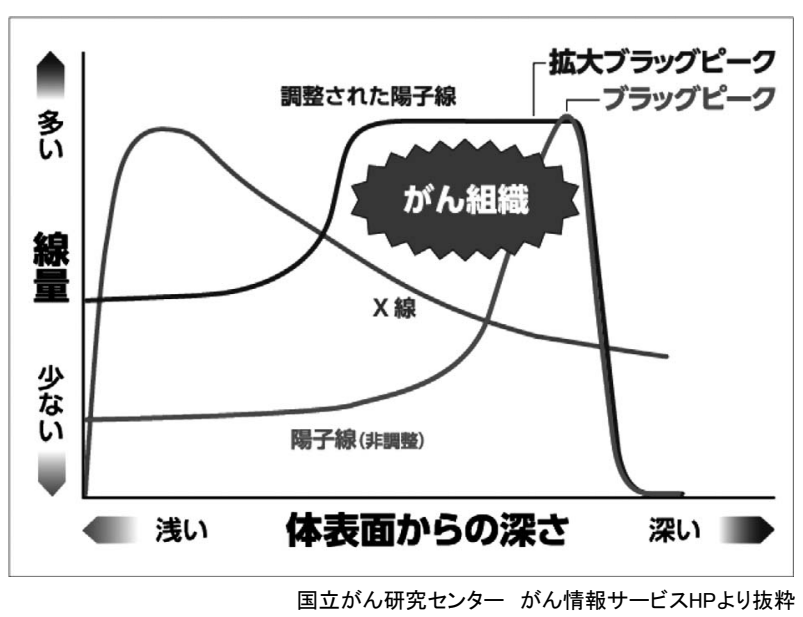

図 2.

肺臓炎等の有害事象の低減が期待される。

肺癌領域ではターゲットの呼吸性移動が問題となるこ とが多く, 必要に応じて呼吸性移動対策が取られている。

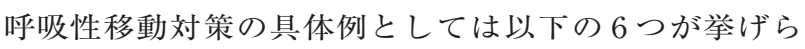
れ, 1 診療報酬上の条件を満たせば呼吸性移動対策加算 が算定される.

(1) 酸素吸入

(2) 腹部圧迫：一般に呼吸は横隔膜運動による要素が 大きいため, 腹部圧迫により呼吸運動を縮小させる方法.

（3）規則性呼吸学習（メトロノーム法）

（4）呼吸停止法：自発的または受動的に同一レベルで 呼吸を停止する方法. 呼吸位相をモニタリングしながら 行うことが多い.

(5) 呼吸同期法：自由呼吸の中で, 呼吸位相中の一定 の部分のみを照射時間にあてるもの.

（6）動体追跡照射法：自由呼吸の中で，呼吸位相と腫 瘍位置の関係を分析し，呼吸位相に合わせて照射野を移 動する追尾法と, 腫瘍の近傍に埋め込んだマーカを透視 下に監視し，ある位置を通過するときのみに照射する迎 撃法がある。

\section{2. 非小細胞肺癌（NSCLC）の放射線治療}

\subsection{II 期 NSCLC}

医学的な理由で手術できない I II 期 NSCLCには, 根 治的放射線治療の適応があり, 行うように勧められてい る. ${ }^{2}$ 特に I 期 NSCLC の場合は, SBRT など線量の集中 性を高める高精度放射線技術を用いることが勧められ る. 線量分割については, $48 \mathrm{~Gy} / 4$ 回 (アイソセンタ処方) が用いられることが多い. 1 ただし, 腫瘍が中枢性病変の 場合は, 重篤な晚期障害のリスクを鑑みて線量分割が変 更されることや，照射適応外となることがある． 


\subsection{III 期 NSCLC}

化学療法と根治的胸部放射線治療の併用療法が可能な 局所進行 NSCLC 患者には，プラチナを含む化学放射線 療法（CRT）を行うよう锥められる. ${ }^{2}$ 通常分割法で 60 Gy を最低合計線量とするよう勧められるが, 74 Gy の高 線量照射は行わないよう勧められる。なお根治照射可能 症例とは, 病変部すべてに対して根治線量を照射可能で, かつ正常組織障害を最小限に抑えることができる症例の 事である，病変部位や既存肺の状態によって，個別に判 断される。

化学放射線療法の適応とならない場合は, 無症状で あっても根治的放射線単独療法の適応があり, 行うよう 钊められる. 2 この場合, 通常線量分割で少なくとも 60 $\mathrm{Gy} / 30$ 回/6 週を行うよう勧められる.

\section{LD-SCLC の放射線治療}

PS 良好な場合, 化学療法と胸部放射線治療の併用療法 が標準治療である.2 併用の夕イミングとしては, 早期同 時併用が勧められる。胸部照射の線量分割法は, AHF45 $\mathrm{Gy} / 30$ 回/3 週を行うよう钊められる. AHF が不可能な 場合は, 通常分割法 50〜 $60 \mathrm{~Gy} / 25 \sim 30$ 回/5〜6 週を行 j.

PS 不良の場合は, 化学療法の施行にて PS が改善すれ ば放射線治療の追加併用を行う. ${ }^{2}$

初期治療で CR が得られた症例では, 予防的全脳照射 (prophylactic cranial irradiation：PCI）を行うことが推 奨される. 2 線量分割は $25 \mathrm{~Gy} / 10$ 回 $/ 2$ 週相当を用いる.

\section{4. 緩和照射}

\section{1 骨転移}

肺癌骨転移に対する放射線治療の有効率は 59 ～73\% と高く, 3 疼痛緩和目的の放射線治療は行うよう勧めら れている. 2 線量分割は $30 \mathrm{~Gy} / 10$ 回/2 週や $8 \mathrm{~Gy} / 1$ 回な どがあり，患者状態や予後によって選択される，外照射 の適応が困難な広範囲の有痛性骨転移の場合は, 骨シン
チグラフィ陽性であれば， Sr 89 を用いた内照射の適応が 検討される. 椎体転移で脊髄圧迫症状を呈する場合は, 速やかな放射線治療が推奨される。 また, 状況に応じ, 骨折予防目的で外照射を行うこともある.

\section{2 脳転移}

肺癌は脳転移の生じる頻度が高く, 生じる様々な神経 症状で QOL は低下しやすい. 放射線治療は対症療法と して有効であり, 行うよう勧められている. ${ }^{2}$ 頭蓋外に活 動性がない単発性脳転移では, SRS もしくは手術を行う よう勧められている。多発性脳転移に対しては，全脳照 射が一般的に行われているが, 少数転移の場合はSRS も行われている。

\section{3 胸部病変（気道狭窄・上大静脈症候群など）}

縦隔・肺門病変による気道狭窄, 上大静脈症候群によ る症状緩和を目的とした胸部放射線治療は，行うよう勧 められている. 2 気道からの出血に対する止血目的の胸 部照射も適応検討しうる。病変局所に対し, $30 \mathrm{~Gy} / 10$ 回（2 週）や $40 \mathrm{~Gy} / 20$ 回（4 週）などで治療を行うこと が多い.

\section{終わりに}

以上，放射線治療における基礎事項について述べた. 肺癌診療における放射線治療の守備範囲は広い。高精度 放射線治療技術のさらなる向上により，肺癌の治療成績 向上につながることが期待される。

本論文内容に関連する著者の利益相反：なし

\section{REFERENCES}

1. 日本放射線腫瘍学会. 放射線治療計画ガイドライン 2016 年版. 金原出版；2016.

2. 日本肺癌学会. $\mathrm{EBM}$ の手法による肺癌診療ガイドライン 2016 年版. 金原出版 ; 2016.

3. Chow E, Zeng L, Salvo N, Dennis K, Tsao M, Lutz S. Update on the systematic review of palliative radiotherapy trials for bone metastases. Clin Oncol (R Coll Radiol). 2012; 24:112-124. 